$\begin{array}{cc}\text { Türkiye Tarımsal Araştırmalar Dergisi } & \text { Turk J Agric Res } \\ \text { http://dergi.siirt.edu.tr } & \text { (2016) 3: 109-121 } \\ \text { O TÜTAD } & \text { ISSN: 2148-2306 } \\ \text { Adoi: 10.19159/tutad.47205 }\end{array}$

\title{
Doğu Anadolu'nun Güneyinde Yetiştirilen Taze Fasulye (Phaseolus vulgaris L.) Gen Kaynaklarının Toplanması ve Fenolojik Bakımdan Değerlendirilmesi*
}

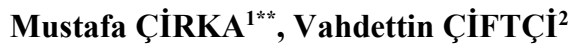

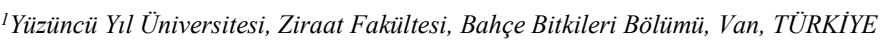 \\ ${ }^{2}$ Abant İzzet Baysal Üniversitesi, Ziraat ve Doğa Bilimleri Fakültesi, Tarla Bitkileri Bölümü, Bolu, TÜRKIYYE
}

\begin{abstract}
Geliş Tarihi/Received: 26.01 .2016
Kabul Tarihi/Accepted: 23.06.2016

${ }^{* *}$ Sorumlu yazar/Corresponding author: $\mathrm{m}_{-}$cirka@hotmail.com

Özet: Bu çalışma 2009-2011 yılları arasında, Doğu Anadolu Bölgesi’nin güneyinde (Bitlis, Bingöl, Muş, Malatya, Tunceli, Elazığ, Hakkâri, Van) taze tüketim için yetiştiriciliği yapılan fasulye popülasyonlarından toplanan 378 genotipin fenolojik özelliklerin belirlenmesi ve taze tüketime yönelik kullanılabilecek ümitvar hatların seçilmesi amacıyla yürütülmüştür. Calıșmada 4F-89 ve Helinda Gold sırık, Yalova-5 ve Yalova-17 bodur fasulye çeșitleri kontrol olarak kullanılmıștır. Toplanan 378 hattın tartılı derecelendirilmesi ve fenolojik gözlemler sonucunda; 2010 yılında, 62 sırık ve 26 bodur; 2011 yılında ise, 88 hattın arasından 30 sırık ve 8 bodur taze fasulye ümitvar hat olarak belirlenmiştir. Çalışma sonunda standart çeşitler ile toplanan ve değerlendirilen hatlar arasında farklılıkların olduğu tespit edilmiştir.
\end{abstract}

Anahtar Kelimeler: Sırık taze fasulye, bodur taze fasulye, seleksiyon, fenolojik özellikler

\section{Collection and Phenological Evaluation of Fresh Bean (Phaseolus vulgaris L.) Germplasm Grown at South of Eastern Anatolia}

\begin{abstract}
The study was carried out to record the phenological features and to identify promising cultivar candidates by selection criteria of 378 collected bean germplasm which were suitable for fresh consumption in South of Eastern Anatolia (Bitlis, Bingöl, Muş, Malatya, Tunceli, Elazığ, Hakkâri, Van) in 2009-2011. In the study, 4F-89 and Helinda Gold pole bean cultivars, Yalova-5 and Yalova-17 dwarf bean cultivars were used as standard control varieties. According to the weighing rating and phenological observations, 62 pole and 26 dwarf fresh beans were identified as promising candidate lines among collected 378 lines in 2010. Among these 86 suitable lines, 30 pole and 8 dwarf fresh beans were observed as promising candidate lines. According to the result of the study, significant differences were determined between the standard cultivars and the local varieties.
\end{abstract}

Keywords: Pole fresh bean, dwarf fresh bean, selection, phenological characteristics

\section{Giriş}

Bitkisel çeşitlilik bakımından önemli bir yere sahip olan sebzeler, özellikle dengeli beslenmede tüketilmesi gerekli olan besin öğelerini içerdiklerinden büyük bir paya sahiptirler. Baklagiller gurubunun önemli bir sebzesi olan fasulye; taze bakla, kuru dane, konserve ve dondurulmuş olarak farklı tüketim şekillerine sahip, besin değeri yüksek bir sebze türüdür (Duke, 1983).

Fasulye; Kuzey ve Orta Amerika, Güney Amerika, Doğu ve Güney Afrika, Batı ve Güney Doğu Avrupa ve Doğu Asya olmak üzere dünyada beş bölgede üretimi yapılmaktadır (Adams ve ark., 1985). Fasulye gen merkezi Güney Amerika ve

*: Bu çalışma, Yüzüncü Yıl Üniversitesi Fen Bilimleri Enstitüsü Doktora Tez çalışmasının bir bölümünden üretilmiştir. 
Orta Amerika'dır (Chacon ve ark., 2005; Benchimol ve ark., 2007; Chiorato ve ark., 2007; Marotti ve ark., 2007; Kwak ve Gepts, 2009).

Güney Amerika'daki iri fasulye tiplerinde yüz tane ağırlığı 40 gramın üzerinde, Orta Amerika'daki küçük fasulye tiplerinde yüz tane ağırlığı 25 gramın altında iken, orta büyüklükteki fasulye tiplerinin yüz tane ağırlığının ise 25-40 gram arasında olduğu rapor edilmiştir (Singh, 2001).

Fasulyede kalite ve verimi; biyolojik (hastalık ve zararlılar), ekolojik (yağış, sicaklık, gün uzunluğu, toprak tipi ve topoğrafya vs.) ve o bölgenin sosyo-ekonomik faktörleri etkilemektedir (Wooly ve ark., 1991).

Fasulye çiçek yapısı ve döllenme biyolojisinin bir sonucu olarak genetik açılmanın az olduğu bir sebze türüdür. Bunun bir sonucu olarak ülkemizde pek çok bölgede üreticiler kendi tohumluklarını kendileri temin etmeyi tercih etmektedirler. Yörelerin tüketim alışkanlıklarının ve ekolojik özelliklerinin farklı olmasından dolayı zaman içinde farklı yörelere özgün yerel fasulye popülasyonları oluşmaktadır. $\mathrm{Bu}$ çalışmayla belirlenen Bingöl, Bitlis, Elazığg, Hakkâri, Malatya, Muş, Tunceli ve Van yörelerindeki üreticiler, yerel popülasyonlarla fasulye yetiştiriciliği yapmakta ve kendi tohumlarını kendileri temin etme alışkanlıklarını sürdürmektedirler.

Nitelikli hatların belirlenmesi, özelliklerinin ortaya konması ve bu hatların tescili ile yeni çeşitlerin elde edilmesi mümkündür. Ayrıca melezleme çalışmalarında nitelikli ebeveyn hatlar olarak kullanılabilmesi son derece önemlidir.

$\mathrm{Bu}$ çalışmada; Doğu Anadolu Bölgesi'nin güneyinde var olan yerel taze fasulye popülasyonları içerisinden Tartılı Derecelendirme Yöntemiyle nitelikli hatlar ile, çalışma neticesinde tüketim alışkanlıklarına ve bölgelerin ekolojik özelliklerine uyumlu ümitvar yeni taze fasulye hatlarının belirlenmesi amaçlanmıştır.

\section{Materyal ve Yöntem}

$\mathrm{Bu}$ araştırma; 2009 yılı Mart ve Ekim ayları arasında Bingöl, Bitlis, Elazı̆̆g, Hakkâri, Malatya, Muş, Tunceli ve Van illerinden yerel taze fasulye genotiplerinin toplanması ile başlamış, 2010 ve 2011 yillarında ise tarla denemeleri kurularak yürütülmüştür.

\subsection{Materyalin toplanması ve isimlendirme çalışmaları}

Yerel fasulye genotiplerin toplanması iki aşamada gerçekleşmiştir. İlk aşamada; kısa sürede toplama işlemini gerçekleştirebilmek amacıyla Gıda, Tarım ve Hayvancılık İl Müdürlükleri ile koordinasyon sağlanarak il genelinde taze tüketime uygun fasulye yetiştirilen alanlar tespit edilmiştir. İkinci aşamada; 2009 yılı Mart ayından başlamak üzere 8 ay süreyle mevcut 8 il gezilerek, taze tüketim amaciyla yetiştirilen fasulye genotipleri toplanmış ve bu genotiplere ait bazı coğrafik bilgiler (yer, köy adı, rakım ve koordinatlar) belirlenmiş; topoğrafya, yetiştirici kimlik bilgileri, çeşidin yetiştiriliş amacı, çeşidin yerel isminin yer aldığı pasaport bilgileri kayıt altına alınmıştır.

Yürütülen genotip toplama çalışması sonucunda, sırık ve bodur olmak üzere toplam 378 adet fasulye örneği toplanmıştır. Toplanan tohum örnekleri şekil, renk ve damarlanma gibi özelliklere bağlı kalarak gruplandırılmıştır. Tohum örnekleri toplandıkları illerin kısaltılmış isimleri ve sonuna eklenen örnek numarası ile adlandırılmıştır. Örneğin, Bitlis ilinden alınan birinci genotip BT-1 olarak isimlendirilmiştir. Çalışmada taze fasulye genotiplerinin toplandığı alanlara ilişkin bazı bilgiler Tablo 1'de, çalışma alanı lokasyon haritası ise Şekil 1'de verilmiştir.

\subsection{Tarla denemeleri ve laboratuvar çalıșması}

Araştırmada tarla denemeleri, 2010 ve 2011 yıllarında, Van'ın Gevaş ilçesinde; laboratuvar çalışmaları ise, Yüzüncü Yıl Üniversitesi Ziraat Fakültesi Tarla Bitkileri Bölümü'nde yürütülmüştür.

\subsubsection{Deneme alanının toprak özellikleri}

Deneme kurulmadan önce alınan toprak örneklerinin bazı fiziksel ve kimyasal analiz sonuçları Tablo 2'de verilmiştir. Tarla denemelerinin yürütüldüğü toprakların siltli tın bünyeli olduğu; hafif alkalin karakterli olan toprakların, çok az düzeyde tuz ve organik madde, orta düzeyde kireç içerdiği ve alınabilir fosfor $(\mathrm{P})$ bakımından fakir olduğu belirlenmiştir (Tablo 2).

\subsubsection{Deneme alanının iklim özellikleri}

Kışları soğuk ve sert, yazlar ise sicak ve kurak geçen bir iklime sahip olan Gevaş ilçesinde, sonbahar aylarında fırtınalar oldukça sert esmektedir. Tarla denemesinin yürütüldüğü döneme ait bazı meteorolojik veriler Tablo 3 'te sunulmuştur. Fasulyenin ekim-hasat dönemini kapsayan aylarda; en yüksek sıcaklık ortalaması 2010 yilında $21.3{ }^{\circ} \mathrm{C}$ ile Temmuz ayında görülürken, 2011 yılında $21.2{ }^{\circ} \mathrm{C}$ ile Ağustos ayında tespit edilmiştir. Aynı dönemde 6 aylık periyotta 2010 yilında toplam $176.3 \mathrm{~mm}, 2011$ y1lında ise toplam $297.5 \mathrm{~mm}$ yağış kaydedilmiştir (Tablo 3). 
Tablo 1. Seçilen taze fasulye genotiplerinin bazı alan bilgileri (2009 yılı)

\begin{tabular}{|c|c|c|c|c|c|}
\hline Genotip Ad1 & Toplandiğg yer & Köyü & Toplanılan kişi & Yükselti (m) & Koordinantlar \\
\hline $\mathrm{BN}-8$ & Bingöl/Merkez & Alatepe & Osman Kizgin & 1154 & $39^{\circ} 03502 / 40^{\circ} 45401$ \\
\hline $\mathrm{BN}-12$ & Bingöl/merkez & Çobantaş1 & Abdullah Korkmaz & 1542 & $39^{\circ} 04033 / 40^{\circ} 48557$ \\
\hline $\mathrm{BN}-18$ & Bingö1/Kiğ1 & Güneyağıl & Murat Yaman & 1489 & $39^{\circ} 17427 / 40^{\circ} 20136$ \\
\hline $\mathrm{BN}-23$ & Bingö1/Kiğ 1 & Güneyağıl & Murat Yaman & 1489 & $39^{\circ} 17427 / 40^{\circ} 20136$ \\
\hline $\mathrm{BN}-25$ & Bingöl/Solhan & Kavaklıdere & Murat Beroje & 1176 & $38^{0} 55287 / 40^{\circ} 56822$ \\
\hline $\mathrm{BN}-28$ & Bingö1/Yedisu & Elmalı & B.Ü.Z.F. & - & - \\
\hline $\mathrm{BN}-32$ & Bingö1/Yedisu & Elmalı & B.Ü.Z.F & - & - \\
\hline $\mathrm{BN}-37$ & Bingö1/Yedisu & Muz & B.Ü.Z.F & - & - \\
\hline BN-39 & Bingöl/Yedisu & Şen & B.Ü.Z.F & - & - \\
\hline $\mathrm{BN}-58$ & Bingöl/Yedisu & Kara Polat & B.Ü.Z.F & - & - \\
\hline BN-64 & Bingö1/Yedisu & Merkez & B.Ü.Z.F & - & - \\
\hline HK-8 & Hakkâri/Merkez & Otluca & Kerem Çiftçi & 2096 & $37^{\circ} 36105 / 43^{\circ} 41643$ \\
\hline HK-18 & Hakkâri/Merkez & Üzümcü & Şemsettin Uçar & 1135 & $37^{\circ} 29773 / 43^{\circ} 34389$ \\
\hline HK-20 & Hakkâri/Merkez & Üzümcü & Şemsettin Uçar & 1135 & $37^{\circ} 29773 / 43^{\circ} 34389$ \\
\hline HK-30 & Hakkâri/Merkez & Bay & Salih Firat & 1832 & $37^{\circ} 32687 / 43^{\circ} 43333$ \\
\hline HK-31 & Hakkâri/Merkez & Bay & Salih Firat & 1832 & $37^{\circ} 32687 / 43^{\circ} 43333$ \\
\hline HK-33 & Hakkâri/Merkez & Bay & Salih Frrat & 1832 & $37^{\circ} 32687 / 43^{\circ} 43333$ \\
\hline HK-36 & Hakkâri/Merkez & Merzan & Eşref Öztürk & 1993 & $37^{\circ} 34095 / 43^{\circ} 42308$ \\
\hline HK-37 & Hakkâri/Merkez & Merzan & Eşref Öztürk & 1993 & $37^{\circ} 34095 / 43^{\circ} 42308$ \\
\hline HK-38 & Hakkâri/Merkez & Merzan & Eşref Öztürk & 1993 & $37^{\circ} 34095 / 43^{\circ} 42308$ \\
\hline HK-46 & Hakkâri/Merkez & Durankaya & Mehmet Halit Gök & 1764 & $37^{\circ} 33418 / 43^{\circ} 37329$ \\
\hline HK-51 & Hakkâri/Merkez & Rezan & Necmettin Bozkurt & 1601 & $37^{\circ} 42104 / 43^{\circ} 56276$ \\
\hline HK-56 & Hakkâri/Yüksekova & Bağışl1 & Eyüp Yoldaş & 1811 & $37^{\circ} 43279 / 44^{\circ} 02206$ \\
\hline BT-5 & Bitlis/Hizan & Merkez & Siddık Yepelek & 1629 & $38^{\circ} 13424 / 42^{\circ} 21614$ \\
\hline BT-13 & Bitlis/Hizan & Akbıyık & Mehmet Korkmaz & 1522 & $38^{\circ} 11967 / 42^{\circ} 20644$ \\
\hline BT-38 & Bitlis/Hizan & Soğuksu & Yılmaz Çelik & 1365 & $38^{\circ} 06783 / 42^{\circ} 33292$ \\
\hline BT-40 & Bitlis/Hizan & Gayda & Hamdi Kaya & 1271 & $38^{\circ} 10051 / 42^{\circ} 22985$ \\
\hline BT-52 & Bitlis/Merkez & Kuşlu & Ali Ay & 1615 & $38^{\circ} 19739 / 42^{\circ} 14841$ \\
\hline BT-66 & Bitlis/Mutki & Yumrumeşe & Kenan Y1lmaz & 1459 & $38^{\circ} 26765 / 41^{\circ} 51660$ \\
\hline BT-68 & Bitlis/Mutki & Kavakbaşı & Sadullah Ulu & 1303 & $38^{\circ} 28884 / 41^{\circ} 48924$ \\
\hline BT-69 & Bitlis/Mutki & Kavakbaşı & Sadullah Ulu & 1303 & $38^{\circ} 28884 / 41^{\circ} 48924$ \\
\hline BT-71 & Bitlis/Mutki & Yenidoğan & Mehmet Can & 1197 & $38^{\circ} 29116 / 41^{\circ} 47168$ \\
\hline BT-73 & Bitlis/Mutki & Çiftlikyol & Müzeyyen Kardeş & 1259 & $38^{\circ} 30098 / 41^{\circ} 46302$ \\
\hline BT-76 & Bitlis/Mutki & Çiftlikyol & Müzeyyen Kardeş & 1259 & $38^{\circ} 30098 / 41^{\circ} 46302$ \\
\hline BT-83 & Bitlis/Güroymak & Yazlıkonak & Barış Özkan & 1810 & $38^{\circ} 30257 / 42^{\circ} 07150$ \\
\hline BT-114 & Bitlis/Merkez & Çınarbaşı & Kenan Yilmaz & 1459 & $38^{\circ} 26765 / 42^{\circ} 51660$ \\
\hline BT-121 & Bitlis/Mutki & Yumru eşe & Kenan Y1lmaz & 1459 & $38^{\circ} 26765 / 42^{\circ} 51660$ \\
\hline BT-123 & Bitlis/Güroymak & Yazlıkonak & Barış Özkan & 1615 & $38^{\circ} 19739 / 42^{\circ} 14841$ \\
\hline BT-124 & Bitlis/Güroymak & Yazlıkonak & Barış Özkan & 1615 & $38^{\circ} 19739 / 42^{\circ} 14841$ \\
\hline ML-1 & Malatya/Doğanşehir & Erkenek & Nuri Balyemez & 1388 & $37^{\circ} 55785 / 37^{\circ} 56501$ \\
\hline ML-2 & Malatya/Doğanşehir & Erkenek & Nuri Balyemez & 1389 & $37^{\circ} 55785 / 37^{\circ} 56502$ \\
\hline ML-5 & Malatya/Doğanşehir & Erkenek & Nuri Balyemez & 1388 & $37^{\circ} 55785 / 37^{\circ} 56501$ \\
\hline ML-14 & Malatya/Doğanşehir & Savaklı & Gafar Çetintaş & 1364 & $38^{\circ} 02576 / 37^{\circ} 54593$ \\
\hline ML-20 & Malatya/Doğanşehir & Elmalı & Adem Kubat & 1410 & $38^{\circ} 03339 / 37^{\circ} 44688$ \\
\hline ML-21 & Malatya/Doğanşehir & Elmalı & Adem Kubat & 1410 & $38^{\circ} 03339 / 37^{\circ} 44688$ \\
\hline ML-25 & Malatya/Doğanşehir & Ç1ğlık & Zeynep Yıldırım & 1235 & $38^{\circ} 06477 / 37^{\circ} 55440$ \\
\hline ML-30 & Malatya/Doğanşehir & Güroba & Bekir Yıldırım & 1459 & $38^{\circ} 05052 / 37^{\circ} 57494$ \\
\hline ML-32 & Malatya/Doğanşehir & Çömlekoba & Sadiye Doğan & 1370 & $38^{\circ} 05372 / 37^{\circ} 56691$ \\
\hline ML-36 & Malatya/Doğanşehir & Polat Beldesi & Mustafa Göğen & 1270 & $38^{\circ} 09447 / 37^{\circ} 51215$ \\
\hline ML-37 & Malatya/Doğanşehir & Polat Beldesi & Mustafa Göğen & 1270 & $38^{\circ} 09447 / 37^{\circ} 51215$ \\
\hline ML-42 & Malatya/Doğanşehir & Polat Beldesi & Mustafa Göğen & 1270 & $38^{\circ} 09447 / 37^{\circ} 51215$ \\
\hline ML-44 & Malatya/Akçadağ & Ören & Tülay Kınık & 1158 & $38^{\circ} 14905 / 37^{\circ} 55605$ \\
\hline ML-46 & Malatya/Hekimhan & Çayevleri & Raziye Y1lmaz & 1457 & $38^{\circ} 48854 / 37^{\circ} 54964$ \\
\hline ML-47 & Malatya/Hekimhan & Çayevleri & Raziye Y1lmaz & 1457 & $38^{\circ} 48854 / 37^{\circ} 54964$ \\
\hline ML-50 & Malatya/Hekimhan & Çayevleri & Zeynep Pektaş & 1457 & $38^{\circ} 48854 / 37^{\circ} 54964$ \\
\hline
\end{tabular}

B.Ü.Z.F.: Bingöl Üniversitesi Ziraat Fakültesi 
Tablo 1. (devamı)

\begin{tabular}{|c|c|c|c|c|c|}
\hline Genotip ad 1 & Toplandığ1 yer & Köyü & Toplanılan kişi & Yükselti (m) & Koordinantlar \\
\hline ML-54 & Malatya/Doğanşehir & Merkez & Perihan Umur & 1280 & $38^{\circ} 06477 / 37^{\circ} 55440$ \\
\hline ML-58 & Malatya/Doğanşehir & Kurucaova & Yaşar Sülü & 1369 & $37^{\circ} 59707 / 38^{\circ} 01503$ \\
\hline ML-60 & Malatya/Doğanşehir & Kurucaova & Mehmet Arslan & 1369 & $37^{\circ} 59707 / 38^{\circ} 01503$ \\
\hline ML-64 & Malatya/Doğanşehir & Güroba & Fatma Sar1 & 1465 & $38^{\circ} 05052 / 37^{\circ} 57494$ \\
\hline ML-71 & Malatya/Doğanşehir & Güroba & Fatma Sar1 & 1465 & $38^{\circ} 05052 / 37^{\circ} 57494$ \\
\hline ML-73 & Malatya/Doğanşehir & Güroba & Fatma Sar1 & 1465 & $38^{\circ} 05052 / 37^{\circ} 57494$ \\
\hline $\mathrm{TN}-8$ & Tunceli/Pertek & Beydamı & Turabi Üzgün & - & - \\
\hline TN-9 & Tunceli/Pertek & Beydamı & Turabi Üzgün & - & - \\
\hline $\mathrm{TN}-12$ & Tunceli/Pertek & Beydamı & Turabi Üzgün & - & - \\
\hline VN-1 & Van/Gürpınar & Merkez & M.Zeki Çelenk & 1748 & $38^{\circ} 19126 / 43^{\circ} 22555$ \\
\hline VN-16 & Van/Çatak & Bilgi & Abdusselam Yabaş & 1702 & $38^{\circ} 05736 / 43^{\circ} 15575$ \\
\hline VN-17 & Van/Çatak & Bilgi & Abdusselam Yabaş & 1702 & $38^{\circ} 05736 / 43^{\circ} 15575$ \\
\hline VN-19 & Van/Çatak & Alacayar & Faysal Yağmur & 1629 & $38^{\circ} 01890 / 43^{\circ} 08884$ \\
\hline $\mathrm{VN}-23$ & Van/Çatak & Merkez & İrfan Selçuklu & 1502 & $38^{\circ} 00451 / 43^{\circ} 03619$ \\
\hline $\mathrm{VN}-28$ & Van/Başkale & Albayrak & Cavit Yüzer & 2072 & $38^{\circ} 08452 / 44^{\circ} 12332$ \\
\hline VN-48 & Van/Çatak & Merkez & İrfan Selçuklu & 1502 & $38^{\circ} 00451 / 43^{\circ} 03619$ \\
\hline VN-49 & Van/Gürpınar & Merkez & M.Zeki Çelenk & 1748 & $38^{\circ} 19126 / 43^{\circ} 22555$ \\
\hline VN-50 & Van/Gürpınar & Merkez & M.Zeki Çelenk & 1748 & $38^{\circ} 19126 / 43^{\circ} 22555$ \\
\hline VN-59 & Van/Çatak & Elmac1 & Mehmet Faysal & 1807 & $38^{\circ} 04867 / 43^{\circ} 04475$ \\
\hline VN-62 & Van/Bahçesaray & Ünlüce & Perinaz Y1ldiz & 1702 & $38^{\circ} 31128 / 42^{\circ} 19587$ \\
\hline VN-67 & Van/Bahçesaray & Elmayaka & Necat Aykut & 1705 & $38^{\circ} 30546 / 42^{\circ} 19126$ \\
\hline EL-15 & Elazı $\breve{g} /$ Maden & Maden & Suphi Kılıç & 1290 & $38^{\circ} 28865 / 39^{\circ} 31154$ \\
\hline EL-18 & Elazığ/Maden & Kizıltepe & Suphi Kılıç & 1291 & $38^{\circ} 28865 / 39^{\circ} 31155$ \\
\hline EL-25 & Elazı $\breve{g} / M a d e n$ & Yildizhan & Abdullah Erginöz & 1313 & $38^{\circ} 21174 / 39^{\circ} 22660$ \\
\hline EL-42 & Elazığ/Maden & Gezin & Eşref Ozan & 1266 & $38^{\circ} 31233 / 39^{\circ} 31880$ \\
\hline MŞ-9 & Muş/Bulanık & Balotu & Atilla Özben & 1489 & $39^{\circ} 0672 / 42^{\circ} 08046$ \\
\hline MŞ-11 & Muş/Bulanık & Balotu & Ferhat Karakoç & 1489 & $39^{\circ} 06752 / 42^{\circ} 08046$ \\
\hline MŞ-17 & Muş/Bulanık & Değirmensuyu & Mehmet Kara & 1463 & $39^{\circ} 13447 / 42^{\circ} 50513$ \\
\hline MŞ-24 & Muş/Hasköy & Merkez & Şemsettin Yüzer & 1350 & $38^{\circ} 37925 / 41^{\circ} 45735$ \\
\hline MŞ-39 & Muş/Varto & Tepeköy & Hayrettin Özer & 1280 & $39^{\circ} 05383 / 41^{\circ} 30168$ \\
\hline MŞ-42 & Muş/Varto & Özenç & Mehmet Korkmaz & 1468 & $39^{\circ} 06895 / 41^{\circ} 30281$ \\
\hline MŞ-46 & Muş/Bulanık & Güllüova & Eyüp Ayhan & 1550 & $39^{\circ} 03619 / 42^{\circ} 19105$ \\
\hline MŞ-48 & Muş/Bulanık & Güllüova & Eyüp Ayhan & 1550 & $39^{\circ} 03619 / 42^{\circ} 19105$ \\
\hline
\end{tabular}

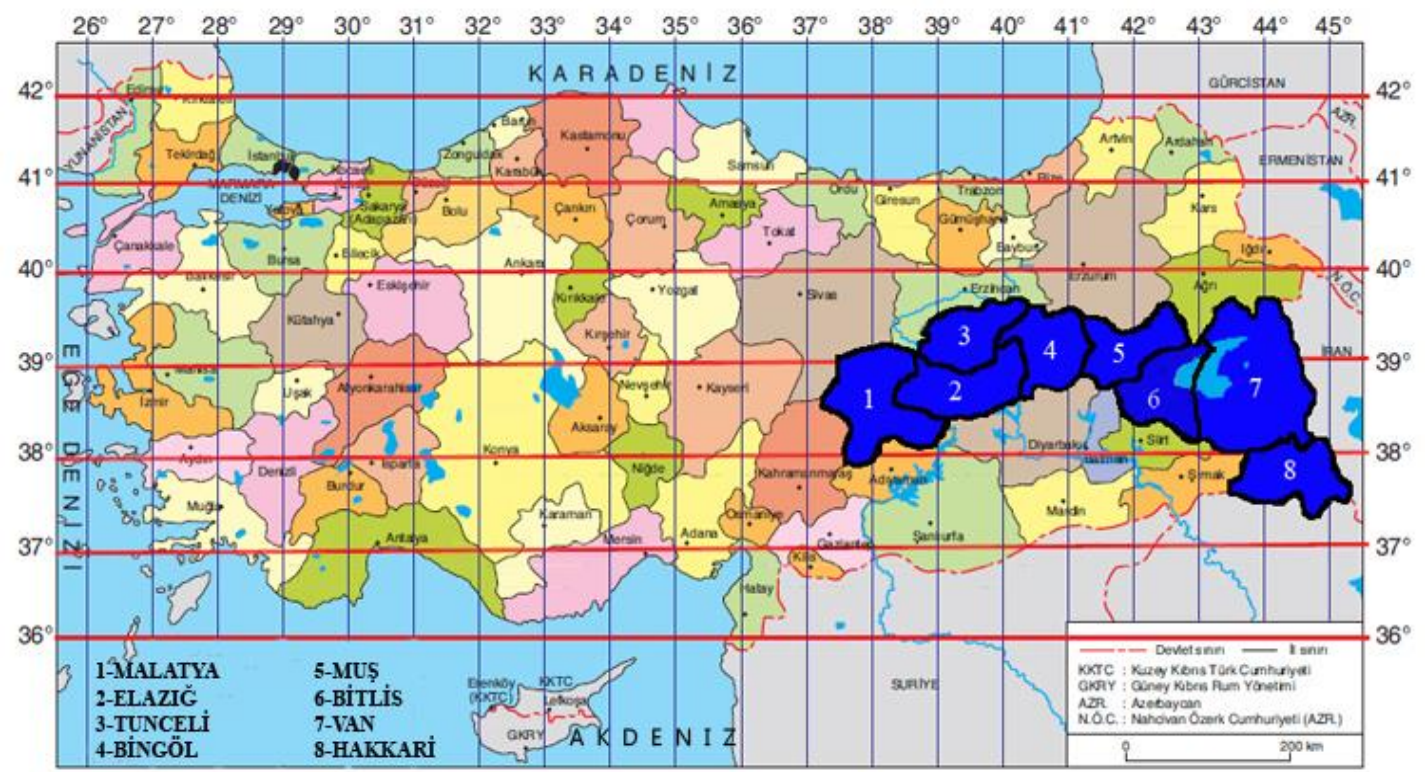

Şekil 1. Çalışma alanı (1-8 No'lu alanlar) lokasyon haritası 
Tablo 2. Deneme yeri topraklarının bazı fiziksel ve kimyasal özellikleri $(0-20 \mathrm{~cm})$

\begin{tabular}{llc}
\hline Toprak özelliği & Birim & Değeri \\
\hline Kum & $\%$ & 26 \\
Kil & $\%$ & 10 \\
Silt & $\%$ & 64 \\
pH & & 8.4 \\
Elektriksel iletkenlik (EC) & $\mu \mathrm{S} / \mathrm{cm}$ & 269 \\
Kireç $\left(\mathrm{CaCO}_{3}\right)$ & $\%$ & 10.5 \\
Organik madde & $\%$ & 0.80 \\
Alınabilir fosfor & $\mathrm{ppm}$ & 4.55 \\
\hline
\end{tabular}

Tablo 3. Gevaş ilçesi bazı iklim verileri (Anonim, 2011)

\begin{tabular}{lcccccc}
\hline Aylar & \multicolumn{3}{c}{2010 yılı } & \multicolumn{4}{c}{2011 yılı } \\
\cline { 2 - 7 } & $\begin{array}{c}\text { Ortalama sıcaklık } \\
\left({ }^{\circ} \mathrm{C}\right)\end{array}$ & $\begin{array}{c}\text { Ortalama nisbi } \\
\text { nem }(\%)\end{array}$ & $\begin{array}{c}\text { Toplam yağış } \\
(\mathrm{mm})\end{array}$ & $\begin{array}{c}\text { Ortalama sıcaklık } \\
\left({ }^{\circ} \mathrm{C}\right)\end{array}$ & $\begin{array}{c}\text { Ortalama nisbi } \\
\text { nem }(\%)\end{array}$ & $\begin{array}{c}\text { Toplam yağış } \\
(\mathrm{mm})\end{array}$ \\
\hline Mayıs & 11.8 & 53.9 & 108.9 & 11.6 & 61.8 & 69.4 \\
Haziran & 17.2 & 45.7 & 20.6 & 16.8 & 47.2 & 15.7 \\
Temmuz & 21.3 & 37.8 & - & 20.8 & 44.3 & 40.5 \\
Ağustos & 19.5 & 40.3 & 2.1 & 21.2 & 45.6 & - \\
Eylül & 16.2 & 45.8 & 3.7 & 15.9 & 53.6 & 23.8 \\
Ekim & 10.6 & 52.6 & 41.0 & 7.2 & 63.7 & 148.1 \\
\hline
\end{tabular}

\subsubsection{Denemelerin kurulması}

Denemeler, Şansa Bağlı Bloklar Deneme Deseni'nde 3 tekrarlamalı olarak kurulmuş ve her parselde 40 bitki olacak şekilde ekimler yapılmıştır. Üreticilerin verdiği bilgiler doğrultusunda illerden toplanan bodur ve sirık fasulye popülasyonlarına ait tohumlar, renk ve şekil bakımından değerlendirilerek ayrı sıralar halinde ekilmiştir. Ekimler, 2010 y1lında, 23-24 Mayıs tarihlerinde; 2011 yılında ise, olumsuz hava koşulları nedeniyle 02-03 Haziran tarihlerinde yapılmıştır. Her bir tekerrürdeki parseller bir bitki sırasından oluşmuştur. Sırık tiplerde, sıra arası 80 $\mathrm{cm}$, sıra üzeri $25 \mathrm{~cm}$; bodur tiplerde ise, sira arası $50 \mathrm{~cm}$, sıra üzeri $15 \mathrm{~cm}$ aralıklarla ekim yapılmıştır. 2011 yılında ise, 2010 yılında tartılı derecelendirme sonucu 390 ve üzeri puan alan 62 sırık ve 26 bodur fasulye genotipi ile deneme kurulmuştur.

Tohumların düzenli bir şekilde çıkışlarını sağlamak için kaymak tabakası kırılmıştır. Her iki yılda da deneme alanına ekimle birlikte $15 \mathrm{~kg} \mathrm{da}^{-1}$ diamonyum fosfat (DAP) gübresi verilmiştir. Çapalama işlemi, fide dönemi ile çiçeklenme dönemi arasında $3 \mathrm{kez}$; taze ve kuru hasat dönemlerinde ise parseller arasındaki yabancı ot varlığına bağlı olarak 2 kez yapılmıştır. Bitkilerin su ihtiyacı, salma sulama şeklinde yapılmıştır. Sulama sıklığı ya da sulama aralığı, hava sıcaklığ ve toprağın nem durumuna bağlı olarak yıl içerisinde 7-9 defa yapılmıştır.

\subsection{4. Çalışmada incelenen gözlem ve ölçümler}

İlk y1l (2010 y1l1), 378 genotip; 2011 y1lında ise, 88 genotipte bazı fenolojik özellikler incelenmiştir. Tartılı derecelendirme metodunda kullanılmak üzere, bazı meyve özelliklerini belirlemek için her genotipten tesadüfi olarak 9'ar meyve seçilmiştir. 2010'da yapılan ölçümlerde 3735 bakla, 2011 yılında yapılan ölçümlerde ise 774 bakla kullanılmıştır.

Fenolojik karakterizasyonda, Uluslararası Bitki Gen Kaynakları Araştırma Enstitüsü (IBPGR) (Anonymous, 1982) ve Avrupa Bitki Çeşit Birliği (EU CPVO) (Anonymous, 2009) verileri kullanılmıştır. Fenolojik karakterizasyonda kullanılan IBPGR ve EU CPVO verilerinde yer alan bazı özellikler çalışmaya uygun bir şekilde modife edilmiştir.

Araştırmada; çıkış oranı, \% 50 çiçeklenme süresi, \% 50 bakla bağlama süresi ve ilk hasat süresi gibi fenolojik gözlemler belirlenmiştir. Tartılı Derecelendirme Metodunda kullanılan parametreler ise aşağıda verilmiştir:

Bakla şekli: $16 \mathrm{~cm}$ 'den büyük ve yassı olan baklalar uzun-yassı, $16 \mathrm{~cm}$ 'den büyük ve yuvarlak olan baklalar uzun-yuvarlak, 12-16 cm arasında ve yassı olan baklalar orta-yassı, 12 cm'den küçük ve yuvarlak olan baklalar kısa-yuvarlak, 12 cm'den küçük ve yassı olan baklalar kısa yassı şeklinde değerlendirilmiştir.

Baklada gevreklik: Bitkilerden taze olarak toplanan baklalar orta yerinden kolay kırılmaları ve kırılırken tok bir ses çıkarmalarına göre gevrek ya da gevrek değil şeklinde değerlendirilmiştir.

Baklada kılçıklılık: Baklalar orta yerinden kırılarak iplikçik varlığına bakılmış, sert kısmı boyunca iplikçik uzuyorsa kılçıklılık var, iplikçik 
baklanın orta yerine doğru bitiyorsa az kılçıklı ve iplikçik varlığı yoksa kılçıksız olarak değerlendirilmişstir.

Bakla rengi: Görsel olarak bakla rengi gözlenmiş, en yüksek göreceli puanı yeşil ve açık yeşil renge sahip baklalar almıştır.

Baklada kıvrllma: Fazla, az ya da yok şeklinde değerlendirilmiştir. Kıvrılmanın az olması ve baklanın tamamen düz olması göreceli puanlamada en yüksek değerleri almıştır.

Salkımda bakla sayısı: Parsellerden tesadüfi olarak belirlenen 8 'er bitkinin salkımındaki baklalar sayılarak ortalamalarının alınmasıyla değerler oluşturulmuştur. Bu veriler doğrultusunda 1.25 ile 2.00 değer arasinda olanlar, 2.00 ve 4.21 değer arasında olanlar ve 4.21'den fazla olanlar şeklinde 3 grup altında değerlendirilerek puanlandırılmıştır.

Bitkideki bakla saylsı: Fasulye hatlarının her birinden 8 bitkiden toplanan baklalar bitki sayısına bölünerek hesaplanmıştır.

\% 50 çiçeklenme dönemi: Denemede yer alan her bir genotip üzerinde yapılan \% 50 çiçeklenme tarihi aynı değerlerle belirtilmiştir. Sırık formlarda erkenci hatlar 45-60 gün, bodur formlarda erkenci hatlar 35-45 gün, sırık formlarda vakitli hatlar 5070 gün, bodur formlarda vakitli hatlar 45-50 gün ve sırık formlarda geççi hatlar ise 70 gün, bodur formlarda geççi hatlar 51 günden fazla olarak belirlenmiştir.
Erkencilik: İlk hasat tarihi dikkate alınarak, bu zaman zarfında geçen gün sayısı hesaplanmıștır. Buna göre; sırık hatlarda 70 günden az olanlar erkenci, 71-81 gün arası olanlar vakitli ve 82 günden fazla olanlar geççi hatlar olarak değerlendirilmiştir. Aynı durum bodur hatlarda 4050 gün arasında olanlar erkenci, 51-70 gün arasında olanlar vakitli ve 71 günden fazla olanlar ise geççi hatlar olarak tespit edilmiştir.

Baklada tohumun belirginliği: Uluslararası Yeni Bitki Çeşitlerini Koruma Birliği (UPOV, The International Union for the Protection of New Varieties of Plants) kriterlerine bağlı kalınarak değerlendirme yapılmış (Balkaya, 1999) ve tohumun bakladaki varlığ belirgin, az belirgin ve belirgin değil şeklinde tanımlanmıştır. Değerlendirmede baklada tohumun belirgin olmadığı hatlar en yüksek göreceli puanı almıştır.

Meyvede pürüzlülük: Parmakla dokunularak kontrol edilen baklaların geneli dikkate alınarak, düz, az pürüzlü, çok pürüzlü olarak değerlendirilmiştir.

Bitki görünümü: Bitki, makinalı hasada uygun olup olmadığı görsel olarak belirlenmiş olup bu doğrultuda dağınık ya da toplu olarak kayıt altına alınmıştır.

Çalışmada kullanılan seleksiyon kriterlerine ait sınıflar, sınıf puanları ve değerler puanı Tablo 4'te verilmiştir.

Tablo 4. Taze fasulyede yapılan seleksiyon kriterlerine ait sinıflar, sınıf puanları ve değerler puanı (Balkaya, 1999)

\begin{tabular}{|c|c|c|c|c|}
\hline Kriterler & Sinıflar & GP & SP & $\mathrm{GP} * \mathrm{SP}$ \\
\hline \multirow{6}{*}{ Bakla şekli } & Uzun-Yuvarlak & 2 & \multirow{6}{*}{10} & 20 \\
\hline & Uzun-Yass1 & 5 & & 50 \\
\hline & Orta yuvarlak & 4 & & 40 \\
\hline & Uzun yassı & 2 & & 20 \\
\hline & Kisa-Yuvarlak & 1 & & 10 \\
\hline & K1sa-Yass1 & 2 & & 20 \\
\hline \multirow{2}{*}{ Baklada gevreklik } & Var & 5 & \multirow{2}{*}{10} & 50 \\
\hline & Yok & 1 & & 10 \\
\hline \multirow{2}{*}{ Baklada kılçıklılık } & Var & 1 & \multirow{2}{*}{15} & 15 \\
\hline & Yok & 5 & & 75 \\
\hline \multirow{4}{*}{ Bakla rengi } & Sar1 & 1 & \multirow{4}{*}{10} & 10 \\
\hline & Aç1k yeşil & 4 & & 40 \\
\hline & Yeşil & 5 & & 50 \\
\hline & Koyu yeşil & 2 & & 20 \\
\hline \multirow{3}{*}{ Baklada kıvrılma } & Yok & 5 & \multirow{3}{*}{8} & 40 \\
\hline & $\mathrm{Az}$ & 3 & & 24 \\
\hline & Fazla & 1 & & 8 \\
\hline \multirow{3}{*}{ Salkımda bakla sayısı } & 1 & 2 & \multirow{3}{*}{10} & 20 \\
\hline & 2 & 4 & & 40 \\
\hline & 3'ten fazla & 5 & & 50 \\
\hline
\end{tabular}


Tablo 4. (devami)

\begin{tabular}{lcccc}
\hline Kriterler & Sinıflar & GP & SP & GP*SP \\
\hline \multirow{2}{*}{ Bitkide bakla sayıs1 } & Az & 1 & & 8 \\
& Normal & 4 & 8 & 32 \\
& Fazla & 5 & & 40 \\
\hline \multirow{3}{*}{ Çiçeklenme dönemi } & Uzun (52-60 gün) & 5 & & 25 \\
& Normal (46-50 gün) & 4 & 5 & 20 \\
& Kisa (40-43 gün) & 2 & & 10 \\
\hline \multirow{2}{*}{ Erkencilik } & Erkenci (40-50 gün) & 5 & & 25 \\
& Vakitli (51-69 gün) & 4 & 5 & 20 \\
& Geçci (70 günden fazla) & 2 & & 10 \\
Baklada tohumun belirginlik durumu & Belirgin & 2 & & 16 \\
& Az belirgin & 4 & 8 & 32 \\
& Belirgin değil & 5 & & 40 \\
\hline \multirow{3}{*}{ Baklada pürüzlülük } & Pürüzlü & 1 & & 6 \\
& Az pürüzlü & 3 & 6 & 18 \\
Bitki görünümü̈ & Düz & 5 & & 30 \\
\hline
\end{tabular}

GP: Göreceli Puan, SP: Sınıf Puanı

\section{Bulgular ve Tartışma}

\subsection{Toplanan taze tüketime uygun fasulye genotiplerinin bazı fenolojik özellikleri}

Van-Gevaş koşullarında 2010 yılında 23-24 Mayıs tarihlerinde ekilen fasulye genotiplerinde sırık formlarda, \% 50 çiçeklenme 25-30 Temmuz tarihleri arasında en erken 61 gün ile MŞ-39 ve en uzun 67 gün ile BT-52 genotipi olurken; bodur formlarda, \% 50 çiçeklenme 13-16 Temmuz tarihleri arasında en erken 49 gün ile HK-56 genotipi ve 52 gün ile en uzun ML-5 ve HK-79 genotipleri olmuştur (Tablo 5). Araştırmada, 2010 yılında sırık formlarda, \% 50 çiçeklenme süreleri genotipler arasında 5 günlük bir fark gösterirken; bodur formlar arasında ise bu farklılık, en fazla 3 gün olmuştur. Genotipler arasındaki $\% \quad 50$ çiçeklenme sürelerine ait bu farklılıklar, hasat sürelerinde de aynı oranda kendini göstermiştir.

Tarla denemesinin ikinci y1lında (2011) ise; 0203 Haziran tarihlerinde ekilen taze sırık fasulye genotiplerinde \% 50 çiçeklenme 24-30 Temmuz tarihleri arasında en erken 50 gün ile $\mathrm{VN}-16$ genotipi ile Helinda Gold çeşidi ve en uzun 75 gün ile HK-51 genotipinde görülürken, bodur tiplerde 22 Temmuz ile 30 Ağustos tarihleri arasında en erken 43 gün ile Yalova-17 çeşidi ve en uzun 66 gün ile HK-8 genotipi olmuştur (Tablo 6). Çiçeklenme süreleri (\% 50) arasındaki farklıklar sırık formlarda 6 gün, bodur formlarda ise 8 gün olarak gözlemlenmiştir. Balkaya (1999), \% 50 çiçeklenme gün sayısını bodur formlarda 39 gün ile 51 gün ve sirık formlarda ise bu durumun 42 gün ile 73 gün arasında değiştiğini bildirmiştir. Yine aynı çalışmada \% 50 bakla bağlama süresi bodur formlarda 41-53 gün, sırık formlarda 47-87 gün arasında değiştiğini ve ilk hasat tarihinin ise bodur tiplerde 53-63 gün, sırık tiplerde 59-124 gün arasında değiştiğini rapor etmiştir.

Tarla çalışmasının ilk yılı (2010) denemelerinde; sırık tiplerde, \% 50 bakla bağlama süresi 07-31 Ağustos tarihlerinde; bodur tiplerde, 19 Temmuz-10 Ağustos tarihleri arasında gerçekleşmiştir. Bodur formlarda 55 gün ile en erken BN-32, BN-39, BN-58, MŞ-9 ve TN-12 genotipi olurken; en uzun 77 gün ile ML-2 ve ML58 genotipi olmuştur. Sırık formlarda ise, en erken 74 gün ile BT-52, BT-123, BT-124, MŞ-11, MŞ24, MŞ-46, MŞ-48, TN-8, HK-36, HK-37 ve BN23 genotipi olurken, en uzun 98 gün ile TN-9, HK31 ve HK-46 genotipi olmuştur (Tablo 5). Sırık tiplerde \% 50 bakla bağlama süreleri arasındaki farklılıklar sırık tiplerde en fazla 24 gün olarak gerçekleşirken bodur tiplerde 22 gün olmuştur.

İkinci y1lda ise; 02-03 Haziran tarihlerinde ekilen fasulye hatlarında \% 50 bakla bağlama süresi, 29 Temmuz-10 Eylül tarihleri arasında iken; bodur tiplerde, 22 Temmuz-16 Ağustos tarihleri arasında görülmüştür. Bodur taze formlarda en erken 50 gün ile Yalova-17 çeşidi olurken, en uzun 75 gün ile HK-8 genotipi olmuştur. Sirık taze formlarda ise en erken 57 gün ile $\mathrm{VN}-16$ ve Helinda Gold tiplerinde görülürken, en uzun 88 gün ile HK-51 genotipinde görülmüştür (Tablo 6). \% 50 bakla bağlama arasında süreler sırık formlarda 12 gün, bodur formlarda ise 25 gün olarak gözlemlenmiştir

Araştırmanın 2010 yılında; sırık tiplerde, ilk hasat tarihi 13 Ağustos-6 Eylül tarihleri; bodur tiplerde, 23 Temmuz-16 Ağustos tarihleri arasında 
gerçekleşmiștir. Sırık formlarda en erken hasat 76 gün ile VN-16 genotipinde olurken, en geç 105 gün ile TN-9, HK-31 ve HK-46 genotiplerinde görülmüştür. Bodur formlarda ise en erken hasat 61 gün ile $\mathrm{BN}-39$ ve MŞ-9 genotipi olurken, en geç 83 gün ile ML-2, ML-58 ve HK-79 genotipleri olmuştur (Tablo 5). Sırık tiplerde, ilk hasat süreleri en fazla 13 gün olarak gerçekleşirken; bodur tiplerde, 23 gün olmuştur.

İkinci yıl ise; sırık taze fasulye genotiplerinde, ilk bakla hasadı 3 Ağustos-6 Eylül tarihleri arasında iken; bodur tiplerde, 31 Temmuz-26 Ağustos tarihleri arasında yapılmıştır. Sırık taze hatlarda en erken hasat, 62 gün ile VN-16 genotipi ile Helinda Gold çeşidi olurken; en geç hasat, 96 gün ile HK-51 genotipinde olmuştur. Bodur taze hatlarda en erken hasat, 62 gün ile Yalova-5 çeşidi olurken; en geç hasat, 80 gün ile HK-8 genotipinde görülmüştür (Tablo 6). İlk bakla hasat süreleri arasında süreler sırık formlarda, 28 gün; bodur formlarda ise, 26 gün olarak gözlemlenmiştir.

Tablo 5. Seçilen sırık taze fasulye ve bodur taze fasulye genotiplerinde çiçeklenme, bakla bağlama ve ilk hasat süresi (2010 y1lı)

\begin{tabular}{|c|c|c|c|c|c|c|c|}
\hline Genotip ad 1 & ÇS (gün) & BBS (gün) & İHS (gün) & Genotip adı & ÇS (gün) & BBS (gün) & İHS (gün) \\
\hline \multicolumn{8}{|c|}{ Sirık taze fasulye } \\
\hline$\overline{\mathrm{BT}-5}$ & 63 & 80 & 86 & $\mathrm{HK}-51$ & 65 & 90 & 99 \\
\hline BT-13 & 64 & 80 & 88 & BN-8 & 64 & 80 & 87 \\
\hline BT-38 & 64 & 80 & 87 & $\mathrm{BN}-12$ & 63 & 83 & 90 \\
\hline BT -40 & 63 & 80 & 86 & $\mathrm{BN}-18$ & 63 & 83 & 90 \\
\hline BT-52 & 67 & 74 & 82 & $\mathrm{BN}-23$ & 63 & 74 & 84 \\
\hline BT-66 & 63 & 80 & 87 & $\mathrm{BN}-25$ & 63 & 83 & 90 \\
\hline BT-71 & 64 & 80 & 88 & VN-1 & 63 & 83 & 90 \\
\hline BT-73 & 65 & 80 & 88 & VN-16 & 63 & 69 & 76 \\
\hline BT-76 & 60 & 65 & 79 & VN-17 & 64 & 83 & 90 \\
\hline BT-114 & 65 & 90 & 97 & VN-19 & 63 & 92 & 99 \\
\hline BT-121 & 60 & 77 & 95 & VN-23 & 64 & 82 & 89 \\
\hline BT-123 & 64 & 74 & 85 & VN-28 & 64 & 83 & 91 \\
\hline BT-124 & 65 & 74 & 81 & VN-48 & 62 & 92 & 99 \\
\hline EL-18 & 64 & 90 & 96 & VN-49 & 64 & 92 & 98 \\
\hline EL-25 & 63 & 92 & 99 & VN-50 & 66 & 83 & 90 \\
\hline EL-42 & 63 & 80 & 87 & VN-59 & 63 & 83 & 92 \\
\hline MŞ-11 & 64 & 74 & 82 & VN-62 & 64 & 83 & 90 \\
\hline MŞ-24 & 64 & 74 & 83 & VN-67 & 64 & 90 & 96 \\
\hline MŞ-39 & 61 & 90 & 97 & ML-14 & 67 & 83 & 90 \\
\hline MŞ-42 & 63 & 80 & 87 & ML-21 & 64 & 92 & 100 \\
\hline MŞ-46 & 65 & 74 & 82 & ML-32 & 63 & 80 & 88 \\
\hline MŞ-48 & 64 & 74 & 83 & ML-37 & 64 & 92 & 97 \\
\hline TN-8 & 63 & 74 & 90 & ML-42 & 63 & 83 & 90 \\
\hline TN-9 & 63 & 98 & 105 & ML-44 & 64 & 92 & 98 \\
\hline HK-20 & 63 & 83 & 91 & ML-46 & 65 & 83 & 90 \\
\hline HK-30 & 65 & 93 & 100 & ML-47 & 64 & 83 & 91 \\
\hline HK-31 & 64 & 98 & 105 & ML-50 & 64 & 83 & 90 \\
\hline HK-36 & 64 & 74 & 83 & ML-54 & 64 & 92 & 99 \\
\hline HK-37 & 65 & 74 & 82 & ML-64 & 64 & 80 & 86 \\
\hline HK-38 & 63 & 93 & 100 & ML-71 & 65 & 80 & 87 \\
\hline HK-46 & 64 & 98 & 105 & ML-73 & 65 & 83 & 91 \\
\hline \multicolumn{8}{|c|}{ Bodur taze fasulye } \\
\hline EL-15 & 51 & 60 & 66 & ML-36 & 49 & 70 & 76 \\
\hline $\mathrm{BN}-28$ & 51 & 58 & 64 & ML-58 & 50 & 77 & 83 \\
\hline $\mathrm{BN}-32$ & 51 & 55 & 62 & ML-60 & 51 & 67 & 73 \\
\hline $\mathrm{BN}-37$ & 51 & 58 & 64 & HK-8 & 50 & 66 & 72 \\
\hline $\mathrm{BN}-39$ & 50 & 55 & 61 & HK-18 & 50 & 60 & 66 \\
\hline $\mathrm{BN}-58$ & 51 & 55 & 62 & $\mathrm{HK}-33$ & 51 & 55 & 64 \\
\hline $\mathrm{BN}-64$ & 51 & 58 & 64 & HK-56 & 49 & 60 & 66 \\
\hline ML-1 & 49 & 66 & 72 & MŞ-9 & 51 & 55 & 61 \\
\hline ML-2 & 51 & 77 & 83 & MŞ-17 & 51 & 55 & 66 \\
\hline ML-5 & 52 & 76 & 82 & TN-12 & 51 & 55 & 62 \\
\hline ML-20 & 51 & 58 & 64 & ВТ-69 & 50 & 67 & 73 \\
\hline ML-25 & 50 & 58 & 64 & BT-83 & 51 & 66 & 72 \\
\hline ML-30 & 50 & 58 & 64 & BT-68 & 55 & 60 & 66 \\
\hline
\end{tabular}

ÇS: \% 50 Çiçeklenme Süresi, BBS: \% 50 Bakla Bağlama Süresi, İHS: İlk Hasat Süresi 
Tablo 6. Seçilen sırık taze fasulye ve bodur taze fasulye genotiplerinde çiçeklenme, bakla bağlama ve ilk hasat süresi (2011 yıl1)

\begin{tabular}{|c|c|c|c|c|c|c|c|}
\hline Genotip adı & ÇS (gün) & BBS (gün) & İHS (gün) & Genotip adı & ÇS (gün) & BBS (gün) & İHS (gün) \\
\hline \multicolumn{8}{|c|}{ Sirık taze fasulye } \\
\hline BT-5 & 65 & 70 & 79 & VN-48 & 68 & 80 & 85 \\
\hline BT-38 & 57 & 65 & 79 & VN-49 & 52 & 65 & 79 \\
\hline BT-73 & 59 & 70 & 79 & VN-50 & 54 & 65 & 79 \\
\hline BT-76 & 60 & 65 & 79 & HK-20 & 55 & 65 & 79 \\
\hline BT-123 & 59 & 65 & 80 & HK-37 & 55 & 65 & 79 \\
\hline BT-124 & 58 & 65 & 79 & HK-38 & 70 & 80 & 86 \\
\hline ML-14 & 53 & 65 & 79 & HK-51 & 75 & 88 & 96 \\
\hline ML-44 & 55 & 65 & 79 & EL-42 & 55 & 65 & 79 \\
\hline ML-64 & 50 & 65 & 79 & MŞ-24 & 55 & 65 & 79 \\
\hline ML-71 & 50 & 65 & 79 & MŞ-48 & 56 & 65 & 79 \\
\hline TN-8 & 55 & 65 & 79 & BN-8 & 58 & 65 & 79 \\
\hline VN-1 & 55 & 65 & 79 & BN-12 & 55 & 65 & 79 \\
\hline VN-16 & 50 & 57 & 62 & $\mathrm{BN}-23$ & 57 & 65 & 79 \\
\hline VN-17 & 55 & 65 & 79 & $\mathrm{BN}-25$ & 67 & 80 & 86 \\
\hline VN-19 & 68 & 80 & 86 & $4 \mathrm{~F}-89$ & 55 & 65 & 79 \\
\hline VN-28 & 65 & 80 & 96 & Helinda Gold & 50 & 57 & 62 \\
\hline \multicolumn{8}{|c|}{ Bodur taze fasulye } \\
\hline ML-20 & 50 & 60 & 65 & HK-18 & 50 & 60 & 65 \\
\hline ML-25 & 50 & 60 & 65 & HK-33 & 50 & 60 & 66 \\
\hline ML-30 & 50 & 60 & 65 & Yalova-17 & 43 & 50 & 59 \\
\hline ML-60 & 50 & 60 & 65 & Yalova-5 & 50 & 58 & 62 \\
\hline HK-8 & 66 & 75 & 80 & & & & \\
\hline
\end{tabular}

\subsubsection{Sirlk ve bodur taze fasulye genotiplerinde 2010 yılı tartılı derecelendirme sonuçları}

Birinci yılın sınıf, sınıf puanları ve göreceli puanları Tartılı Derecelendirme Yöntemi'ne göre değerlendirmeleri yapılmış ve sonuçlar sırık ve bodur formlar için Tablo 7'de verilmiştir. Çizelgelerde 390 göreceli puanı aşan genotipler verilmiştir. Göreceli puan olarak 390 ve üzeri puan alan 62 sirık taze ve 26 bodur taze genotip bir sonraki yıl denemeye alınmıştır. Göreceli puanlamada 431 puan ile en yüksek değeri, sırık tiplerden BT-76 genotipi; 451 puan ile en yüksek değeri, bodur tiplerden ML-20 ve BT-68 genotipleri almıştır (Tablo 7).

Araştırmada, 2010 yılında seçilen sırık ve bodur fasulye formlarının baklalarının tamamının gevrek ve kılçıksız olduğu belirlenmiştir. Baklaların gevrek ve kılçıksız oluşu puanlamada en yüksek değeri alırken, gevrek olmayan ve kılçıklı olan fasulye tipleri en düşük değeri alarak elenmiştir. Sırık fasulye hatlarının \% 45.5'inin orta yeşil ve \% 50.5'inin yeşil olduğu, bodur hatların \% 40'ının orta yeşil ve \% 60'ının yeşil olduğu tespit edilmiştir. Fasulye çeşit geliştirme çalıșmalarında baklaları düzgün hatlar bulma hedeflenmektedir. Birinci yıl puanlamayı geçen 62 sırık hattın genelinde kıvrılmanın orta düzeyde olduğu ve sadece BT-124 genotipinin baklalarının düz olduğu saptanmıştır. Aynı yıl seçilen 26 bodur hat içerisinde $\mathrm{BN}-28$ ve $\mathrm{BN}-37$ genotiplerinin baklalarının düz olduğu, HK-33 ve ML-25 genotiplerinin baklalarında kıvrılmanın çok güçlü olduğu belirlenmiştir. Salkımda bakla sayısı 4 ve 4 'ten fazla olan sirık tipler BT-114, BT-121, ML25, BN-23, BN-25, BN-28, HK-38 ve HK-79 olurken, bodur tiplerde $\mathrm{VN}-30, \mathrm{BN}-40, \mathrm{BN}-46$, $\mathrm{BN}-50$ ve $\mathrm{BN}-55$ genotipleri olmuştur (Tablo 7).

Sırık fasulye tiplerinin bakla şekilleri çoğunlukla uzun-yassı iken, bodur tipler ise kısa yuvarlak şekline sahip oldukları gözlemlenmiştir. Sırık tiplerde uzun-yassı bakla şekli en yüksek değeri alırken, bodur tiplerde ise bodur tiplerde kısa-yuvarlak bakla şekli en düşük puanı almıştır. Seçilen sırık ve bodur hatlarda meyve rengi yeşil iken, bakla zemin rengi sarı olan sırık form olan ML-21 genotipine de rastlanmıştır. Seçilen tüm hatların baklalarında az pürüzlülüğün ve pürüzlülüğün olmadığı tespit edilmiştir. Sırık hatlardan VN-28 ile bodur hatlardan HK-8 ve HK33 genotiplerinde baklada tohumun belirgin olmamasından dolayı en yüksek puanı almışlardır (Tablo 7). Sirık fasulye formlarının ilk hasat tarihleri Ağustos ayının ortasından Eylül ayının sonlarına doğru olduğu, bodur hatlarda ise ilk hasat Temmuz ayının son haftasından Ağustos ayının ortasına kadar devam ettiği belirlenmiştir. Erkenci tipler en yüksek puanı alırken, geççi tipler en az puanı almıștır. 
Tablo 7. Seçilen sırık taze fasulye ve bodur taze fasulye genotiplerinin aldığ 1 GPxSP ve toplam puanları (2010 y11)

\begin{tabular}{|c|c|c|c|c|c|c|c|c|c|c|c|c|c|}
\hline Genotip adı & $\mathrm{BŞ}$ & $\mathrm{BG}$ & $\mathrm{BK}$ & $\mathrm{BR}$ & BK1v & SBS & BBS & ÇD & $\mathrm{E}$ & BTB & $\mathrm{BP}$ & $\mathrm{BG}$ & PUAN \\
\hline \multicolumn{14}{|c|}{ Sirık taze fasulye } \\
\hline BT-76 & 50 & 50 & 75 & 40 & 24 & 50 & 40 & 25 & 10 & 32 & 30 & 5 & 431 \\
\hline VN-1 & 50 & 50 & 75 & 50 & 24 & 50 & 32 & 25 & 20 & 32 & 18 & 5 & 431 \\
\hline BT-38 & 50 & 50 & 75 & 40 & 24 & 50 & 40 & 25 & 20 & 32 & 18 & 5 & 429 \\
\hline ML-64 & 50 & 50 & 75 & 40 & 24 & 40 & 50 & 25 & 20 & 32 & 18 & 5 & 429 \\
\hline BT-124 & 40 & 50 & 75 & 50 & 40 & 40 & 40 & 25 & 10 & 16 & 30 & 5 & 421 \\
\hline MŞ-46 & 40 & 50 & 75 & 50 & 24 & 40 & 40 & 25 & 10 & 32 & 30 & 5 & 421 \\
\hline VN-16 & 50 & 50 & 75 & 50 & 24 & 40 & 32 & 25 & 20 & 32 & 18 & 5 & 421 \\
\hline $\mathrm{BN}-23$ & 50 & 50 & 75 & 50 & 24 & 50 & 32 & 25 & 10 & 32 & 18 & 5 & 421 \\
\hline HK-31 & 50 & 50 & 75 & 40 & 24 & 50 & 32 & 25 & 20 & 32 & 18 & 5 & 421 \\
\hline HK-36 & 50 & 50 & 75 & 50 & 24 & 40 & 32 & 25 & 20 & 32 & 18 & 5 & 421 \\
\hline HK-37 & 50 & 50 & 75 & 50 & 24 & 50 & 32 & 25 & 10 & 32 & 18 & 5 & 421 \\
\hline EL-42 & 40 & 50 & 75 & 50 & 24 & 50 & 40 & 25 & 10 & 32 & 18 & 5 & 419 \\
\hline HK-46 & 40 & 50 & 75 & 50 & 24 & 40 & 40 & 25 & 20 & 32 & 18 & 5 & 419 \\
\hline BT-13 & 40 & 50 & 75 & 40 & 24 & 50 & 40 & 25 & 20 & 16 & 30 & 5 & 415 \\
\hline BТ -40 & 40 & 50 & 75 & 50 & 24 & 40 & 40 & 25 & 20 & 16 & 30 & 5 & 415 \\
\hline BT-121 & 40 & 50 & 75 & 50 & 24 & 40 & 40 & 25 & 20 & 16 & 30 & 5 & 415 \\
\hline BT-123 & 40 & 50 & 75 & 50 & 24 & 40 & 40 & 25 & 20 & 16 & 30 & 5 & 415 \\
\hline MŞ-11 & 40 & 50 & 75 & 50 & 24 & 40 & 40 & 25 & 20 & 16 & 30 & 5 & 415 \\
\hline BT-114 & 40 & 50 & 75 & 50 & 24 & 50 & 40 & 25 & 20 & 16 & 18 & 5 & 413 \\
\hline MŞ-24 & 40 & 50 & 75 & 40 & 24 & 40 & 32 & 25 & 20 & 32 & 30 & 5 & 413 \\
\hline MŞ-48 & 40 & 50 & 75 & 40 & 24 & 40 & 32 & 25 & 20 & 32 & 30 & 5 & 413 \\
\hline ML-14 & 50 & 50 & 75 & 50 & 24 & 40 & 40 & 25 & 20 & 16 & 18 & 5 & 413 \\
\hline HK-30 & 50 & 50 & 75 & 50 & 24 & 40 & 50 & 25 & 10 & 16 & 18 & 5 & 413 \\
\hline ML-37 & 50 & 50 & 75 & 40 & 24 & 40 & 32 & 25 & 20 & 32 & 18 & 5 & 411 \\
\hline ML-50 & 50 & 50 & 75 & 40 & 24 & 40 & 32 & 25 & 20 & 32 & 18 & 5 & 411 \\
\hline BN-12 & 40 & 50 & 75 & 50 & 24 & 40 & 32 & 25 & 20 & 32 & 18 & 5 & 411 \\
\hline BN-18 & 50 & 50 & 75 & 40 & 24 & 40 & 32 & 25 & 20 & 32 & 18 & 5 & 411 \\
\hline HK-38 & 50 & 50 & 75 & 40 & 24 & 50 & 32 & 25 & 10 & 32 & 18 & 5 & 411 \\
\hline BT-5 & 40 & 50 & 75 & 40 & 24 & 50 & 40 & 25 & 10 & 32 & 18 & 5 & 409 \\
\hline ВТ-66 & 40 & 50 & 75 & 50 & 24 & 40 & 40 & 25 & 10 & 32 & 18 & 5 & 409 \\
\hline BТ-73 & 40 & 50 & 75 & 50 & 24 & 40 & 40 & 25 & 10 & 32 & 18 & 5 & 409 \\
\hline EL-18 & 40 & 50 & 75 & 40 & 24 & 50 & 40 & 25 & 10 & 32 & 18 & 5 & 409 \\
\hline EL-25 & 40 & 50 & 75 & 40 & 24 & 50 & 40 & 25 & 10 & 32 & 18 & 5 & 409 \\
\hline MŞ-42 & 50 & 50 & 75 & 40 & 24 & 40 & 40 & 25 & 10 & 32 & 18 & 5 & 409 \\
\hline VN-28 & 50 & 50 & 75 & 50 & 24 & 20 & 32 & 25 & 20 & 40 & 18 & 5 & 409 \\
\hline ML-46 & 40 & 50 & 75 & 40 & 24 & 40 & 40 & 25 & 20 & 32 & 18 & 5 & 409 \\
\hline BT-52 & 40 & 50 & 75 & 50 & 24 & 40 & 40 & 25 & 10 & 16 & 30 & 5 & 405 \\
\hline TN-8 & 50 & 50 & 75 & 50 & 24 & 20 & 40 & 25 & 20 & 16 & 30 & 5 & 405 \\
\hline VN-67 & 50 & 50 & 75 & 50 & 24 & 40 & 32 & 25 & 20 & 16 & 18 & 5 & 405 \\
\hline ML-47 & 40 & 50 & 75 & 40 & 24 & 40 & 40 & 25 & 20 & 16 & 30 & 5 & 405 \\
\hline $\mathrm{BN}-25$ & 40 & 50 & 75 & 50 & 24 & 50 & 32 & 25 & 20 & 16 & 18 & 5 & 405 \\
\hline HK-20 & 40 & 50 & 75 & 50 & 24 & 50 & 32 & 25 & 20 & 16 & 18 & 5 & 405 \\
\hline HK-51 & 40 & 50 & 75 & 50 & 24 & 50 & 32 & 25 & 20 & 16 & 18 & 5 & 405 \\
\hline VN-17 & 50 & 50 & 75 & 40 & 24 & 40 & 40 & 25 & 20 & 16 & 18 & 5 & 403 \\
\hline ML-21 & 50 & 50 & 75 & 10 & 24 & 50 & 32 & 25 & 20 & 32 & 30 & 5 & 403 \\
\hline ML-71 & 40 & 50 & 75 & 50 & 24 & 40 & 40 & 25 & 20 & 16 & 18 & 5 & 403 \\
\hline ML-73 & 40 & 50 & 75 & 50 & 24 & 40 & 40 & 25 & 20 & 16 & 18 & 5 & 403 \\
\hline BN-8 & 50 & 50 & 75 & 50 & 24 & 40 & 40 & 25 & 10 & 16 & 18 & 5 & 403 \\
\hline BТ-71 & 40 & 50 & 75 & 50 & 24 & 20 & 40 & 25 & 10 & 32 & 30 & 5 & 401 \\
\hline VN-59 & 40 & 50 & 75 & 40 & 24 & 40 & 32 & 25 & 20 & 32 & 18 & 5 & 401 \\
\hline VN-62 & 50 & 50 & 75 & 40 & 24 & 20 & 40 & 25 & 20 & 32 & 18 & 5 & 399 \\
\hline TN-9 & 50 & 50 & 75 & 40 & 24 & 50 & 8 & 25 & 20 & 32 & 18 & 5 & 397 \\
\hline MŞ-39 & 40 & 50 & 75 & 50 & 24 & 40 & 32 & 25 & 20 & 16 & 18 & 5 & 395 \\
\hline VN-19 & 50 & 50 & 75 & 40 & 24 & 40 & 32 & 25 & 20 & 16 & 18 & 5 & 395 \\
\hline VN-48 & 40 & 50 & 75 & 50 & 24 & 40 & 32 & 25 & 20 & 16 & 18 & 5 & 395 \\
\hline VN-49 & 50 & 50 & 75 & 40 & 24 & 40 & 32 & 25 & 20 & 16 & 18 & 5 & 395 \\
\hline VN-50 & 50 & 50 & 75 & 40 & 24 & 40 & 32 & 25 & 20 & 16 & 18 & 5 & 395 \\
\hline
\end{tabular}

BS: Bakla Sekli, BG: Baklada Gevreklik, BK: Baklada Kılçıklılık, BR: Bakla Rengi, BKıv: Baklada Kıvrılma, SBS: Salkımda Bakla Sayısı, BBS: Bitkide Bakla Sayısı, ÇD: Çiçeklenme Durumu, E: Erkencilik, BTB: Bakla Tohumunun Belirginliği, BP: Baklada Pürüzlülük, BG: Bitki Görünümü 
Tablo 7. (devami)

\begin{tabular}{|c|c|c|c|c|c|c|c|c|c|c|c|c|c|}
\hline Genotip ad1 & $\mathrm{BŞ}$ & $\mathrm{BG}$ & BK & $\mathrm{BR}$ & BKıv & SBS & BBS & ÇD & $\mathrm{E}$ & BTB & $\mathrm{BP}$ & $\mathrm{BG}$ & PUAN \\
\hline ML-32 & 40 & 50 & 75 & 40 & 24 & 50 & 32 & 25 & 20 & 16 & 18 & 5 & 395 \\
\hline ML-42 & 50 & 50 & 75 & 40 & 24 & 40 & 32 & 25 & 20 & 16 & 18 & 5 & 395 \\
\hline ML-44 & 50 & 50 & 75 & 40 & 24 & 40 & 32 & 25 & 20 & 16 & 18 & 5 & 395 \\
\hline VN-23 & 50 & 50 & 75 & 40 & 24 & 20 & 50 & 25 & 20 & 16 & 18 & 5 & 393 \\
\hline ML-54 & 50 & 50 & 75 & 40 & 24 & 20 & 32 & 25 & 20 & 32 & 18 & 5 & 391 \\
\hline \multicolumn{14}{|c|}{ Bodur taze fasulye } \\
\hline$\overline{\text { BT-68 }}$ & 40 & 50 & 75 & 50 & 24 & 40 & 40 & 25 & 20 & 32 & 30 & 25 & 451 \\
\hline ML-1 & 40 & 50 & 75 & 50 & 24 & 40 & 40 & 25 & 20 & 32 & 30 & 25 & 451 \\
\hline ML-20 & 40 & 50 & 75 & 50 & 24 & 40 & 40 & 25 & 20 & 32 & 30 & 25 & 451 \\
\hline EL-15 & 40 & 50 & 75 & 50 & 24 & 50 & 40 & 25 & 20 & 32 & 18 & 25 & 449 \\
\hline HK-8 & 20 & 50 & 75 & 50 & 24 & 50 & 40 & 25 & 20 & 40 & 30 & 25 & 449 \\
\hline MŞ-9 & 20 & 50 & 75 & 40 & 24 & 50 & 40 & 25 & 20 & 32 & 30 & 25 & 431 \\
\hline ML-58 & 40 & 50 & 75 & 40 & 24 & 40 & 40 & 25 & 20 & 32 & 18 & 25 & 429 \\
\hline ML-60 & 20 & 50 & 75 & 50 & 24 & 50 & 40 & 25 & 20 & 32 & 18 & 25 & 429 \\
\hline BN-58 & 20 & 50 & 75 & 50 & 24 & 50 & 40 & 25 & 20 & 32 & 18 & 25 & 429 \\
\hline ML-5 & 40 & 50 & 75 & 40 & 24 & 50 & 40 & 25 & 20 & 16 & 18 & 25 & 423 \\
\hline HK-33 & 20 & 50 & 75 & 40 & 8 & 50 & 40 & 25 & 20 & 40 & 30 & 25 & 423 \\
\hline MŞ-17 & 40 & 50 & 75 & 40 & 24 & 50 & 40 & 25 & 20 & 16 & 18 & 25 & 423 \\
\hline BT-69 & 40 & 50 & 75 & 50 & 24 & 50 & 40 & 25 & 20 & 16 & 6 & 25 & 421 \\
\hline HK-18 & 10 & 50 & 75 & 40 & 24 & 50 & 40 & 25 & 20 & 32 & 30 & 25 & 421 \\
\hline ML-36 & 20 & 50 & 75 & 50 & 24 & 40 & 40 & 25 & 20 & 32 & 18 & 25 & 419 \\
\hline ML-25 & 20 & 50 & 75 & 40 & 8 & 50 & 40 & 25 & 20 & 32 & 30 & 25 & 415 \\
\hline ML-2 & 40 & 50 & 75 & 40 & 24 & 40 & 40 & 25 & 20 & 16 & 18 & 25 & 413 \\
\hline ML-30 & 20 & 50 & 75 & 20 & 24 & 50 & 40 & 25 & 20 & 32 & 30 & 25 & 411 \\
\hline $\mathrm{BN}-28$ & 40 & 50 & 15 & 50 & 40 & 50 & 40 & 25 & 20 & 32 & 18 & 25 & 405 \\
\hline $\mathrm{BN}-37$ & 40 & 50 & 15 & 50 & 40 & 50 & 40 & 25 & 20 & 32 & 18 & 25 & 405 \\
\hline $\mathrm{BN}-39$ & 40 & 50 & 15 & 50 & 24 & 50 & 40 & 25 & 20 & 32 & 30 & 25 & 401 \\
\hline BN-64 & 40 & 50 & 15 & 50 & 24 & 50 & 40 & 25 & 20 & 32 & 30 & 25 & 401 \\
\hline BT-83 & 10 & 50 & 75 & 40 & 24 & 50 & 40 & 25 & 20 & 16 & 18 & 25 & 393 \\
\hline HK-56 & 20 & 50 & 75 & 40 & 24 & 40 & 40 & 25 & 20 & 16 & 18 & 25 & 393 \\
\hline $\mathrm{TN}-12$ & 40 & 50 & 15 & 40 & 24 & 50 & 40 & 25 & 20 & 32 & 30 & 25 & 391 \\
\hline $\mathrm{BI}$ & 40 & 50 & 5 & 0 & 24 & 40 & 40 & 5 & 0 & 32 & 0 & 25 & 1 \\
\hline
\end{tabular}

BS: Bakla Sekli, BG: Baklada Gevreklik, BK: Baklada Kılçıklılık, BR: Bakla Rengi, BKıv: Baklada Kıvrılma, SBS: Salkımda Bakla Sayısı, BBS: Bitkide Bakla Sayısı, ÇD: Çiçeklenme Durumu, E: Erkencilik, BTB: Bakla Tohumunun Belirginliği, BP: Baklada Pürüzlülük, BG: Bitki Görünümü

\subsubsection{Sirık ve bodur taze fasulye genotiplerinde 2011 yılı tartılı derecelendirme sonuçları}

İkinci yıl Tartılı Derecelendirme Yöntemi’yle seçilen 30 sırık taze fasulye ve 8 bodur taze fasulye 400 ve 400 üzeri göreceli puan alarak çeşit çalışmalarında kullanılacak hatlar olmuştur. Göreceli puanlamada 443 puan ile en yüksek değeri sırık hatlardan olan VN-1 genotipi alırken, 401 puan ile en düşük değeri MŞ-24 genotipi almıştır. Bodur formlardan olan ML-20 genotipi 446 puan ile en yüksek değeri alırken, 402 puan ile en düşük değeri HK-33 genotipi almıştır. Denemeye alınan fasulye genotipleri ile Yalova-5, Yalova-17, 4F-89 ve Helinda Gold standart çeşitleri ekilmiştir. Bodur çeşitlerden olan Yalova17 çeşidi Yalova-5 çeşidinden daha yüksek puan almıştır. Sırık standart çeşitlerden olan Helinda Gold çeşidi 440 Puan ile 4F-89 standart çeşidinden daha yüksek değere sahip olmuştur. Ayrıca Sırık fasulye hatlarından olan VN-1 genotipi, standart çeşit olan Helinda Gold ve 4F-89 çeşidinden daha yüksek puan alırken, VN-49, VN-28, TN-8, BN-8, BN-23, ML-14, HK-37, HK-20, BT-38, BT-76 ve
EL-42 genotipleri 4F-89 standart sırık çeşitten daha yüksek puanlar almışlardır (Tablo 8).

Baklaların uzun-yassı, Gevrek, kılçıksız, koyu yeşil, düzgün meyveli, pürüzsüz ve baklada tohumun belirgin olmamasından dolayı Sırık hatlardan VN-1 genotipi ile bodur hatlardan ML20 genotipi en yüksek değerleri almışlardır. Sırık ve bodur hatlarda gevrekliğin bütün genotiplerde aynı olasından dolayı aynı göreceli puanı almışlardır. Sırık tiplerde baklaların \% 41.93'ünün açık yeşil, \% 58.07'sinin yeşil renkte olduğu ve tamamen kılçıksız oldukları tespit edilmiştir (Tablo 8).

Salkımda bakla sayısı sirık taze fasulye tiplerinde 4 ve 4 'ten fazla olan hatlar BT-114, BT121, BN-23, BN-25, HK-33 ve HK-38 genotipi olurken, bodur hatlarda ise ML-25 ve HK-79 genotipi olmuştur. Seçilen hatların erkencilik yönünden sırık tiplerde Ağustos ayının başlarında ilk hasat yapilırken, bodur tiplerde ise bu durum Temmuz ayının ortalarında gerçekleşmiştir. VN19, VN-28, VN-48 ve BN-25 gibi Eylül ayında hasada gelen geççi sırık tipler, erkencilik 
bakımından en düşük değerleri almışlardır (Tablo 8).

Sırık ve bodur hatların tümünün gevrek ve kılçıksız olmasından dolayı taze tüketime uygun olduğu tespit edilmiştir. Sırık ve bodur hatlar bakla zemin rengi yönünden farklllıklar göstermiş, sırık ve bodur hatların çoğunluğunun açı yeşil renkte olduğu ve bodur hatlardan ML-30 genotipi koyu yeşil baklalara sahip olduğu için en az puanı almıştır. Sırık hatlarda baklada kıvrılma düzeyi fazla olan hat gözlemlenmemiş, Bodur hatlardan olan ML-25 genotipinin baklalarının fazla kıvrık olduğu tespit edilmiştir. Bodur genotiplerden ML60 hattı az pürüzlü olduğu için en az puanı almıştır. Baklada tohumun belirginliği HK-8 bodur genotipinde görülmediği için en yüksek değere sahip olmuştur. Sırık hatlarda bu durum birçok genotipte görüldüğünden dolayı birçok hat yüksek değer almıştır, BT-123 ve BT-124 sırık tipler tohumun belirgin oluşundan en az puanı almıştır (Tablo 8).

Tablo 8. Seçilen sırık taze fasulye ve bodur taze fasulye genotiplerinin ve denemeye alınan standart çeşitlerin aldığı GPxSP ve toplam puanları (2011 yılı)

\begin{tabular}{|c|c|c|c|c|c|c|c|c|c|c|c|c|c|}
\hline Genotip ad1 & BŞ & BG & BK & $\mathrm{BR}$ & BKiv & SBS & BBS & ÇD & $\mathrm{E}$ & BTB & $\mathrm{BP}$ & BG & PUAN \\
\hline \multicolumn{14}{|c|}{ S1rık taze fasulye } \\
\hline$\overline{\mathrm{VN}-1}$ & 50 & 50 & 75 & 50 & 24 & 50 & 32 & 25 & 20 & 32 & 30 & 5 & 443 \\
\hline Helinda Gold & 50 & 50 & 75 & 50 & 40 & 50 & 8 & 25 & 25 & 32 & 30 & 5 & 440 \\
\hline BT-76 & 50 & 50 & 75 & 40 & 24 & 40 & 40 & 25 & 20 & 32 & 30 & 5 & 431 \\
\hline EL-42 & 40 & 50 & 75 & 50 & 24 & 40 & 40 & 25 & 20 & 32 & 30 & 5 & 431 \\
\hline $\mathrm{BN}-23$ & 50 & 50 & 75 & 50 & 24 & 50 & 32 & 25 & 20 & 32 & 18 & 5 & 431 \\
\hline BT-38 & 50 & 50 & 75 & 40 & 24 & 50 & 40 & 25 & 20 & 32 & 18 & 5 & 429 \\
\hline ML-14 & 50 & 50 & 75 & 50 & 24 & 40 & 40 & 25 & 20 & 32 & 18 & 5 & 429 \\
\hline $\mathrm{VN}-28$ & 50 & 50 & 75 & 50 & 24 & 40 & 40 & 20 & 10 & 32 & 30 & 5 & 426 \\
\hline HK-20 & 40 & 50 & 75 & 50 & 24 & 40 & 32 & 25 & 20 & 32 & 30 & 5 & 423 \\
\hline VN-49 & 50 & 50 & 75 & 40 & 24 & 50 & 32 & 25 & 20 & 32 & 18 & 5 & 421 \\
\hline $\mathrm{TN}-8$ & 50 & 50 & 75 & 50 & 24 & 20 & 40 & 25 & 20 & 32 & 30 & 5 & 421 \\
\hline HK-37 & 50 & 50 & 75 & 50 & 24 & 40 & 32 & 25 & 20 & 32 & 18 & 5 & 421 \\
\hline $\mathrm{BN}-8$ & 50 & 50 & 75 & 50 & 24 & 40 & 32 & 25 & 20 & 32 & 18 & 5 & 421 \\
\hline BT-73 & 40 & 50 & 75 & 50 & 24 & 40 & 40 & 25 & 20 & 32 & 18 & 5 & 419 \\
\hline $4 F-89$ & 50 & 50 & 75 & 40 & 24 & 40 & 40 & 25 & 20 & 32 & 18 & 5 & 419 \\
\hline BT-123 & 40 & 50 & 75 & 50 & 24 & 50 & 32 & 25 & 20 & 16 & 30 & 5 & 417 \\
\hline VN-19 & 50 & 50 & 75 & 40 & 24 & 40 & 40 & 20 & 10 & 32 & 30 & 5 & 416 \\
\hline HK-38 & 50 & 50 & 75 & 40 & 24 & 50 & 32 & 20 & 20 & 32 & 18 & 5 & 416 \\
\hline VN-48 & 40 & 50 & 75 & 50 & 24 & 50 & 40 & 20 & 10 & 32 & 18 & 5 & 414 \\
\hline MŞ-48 & 40 & 50 & 75 & 40 & 24 & 40 & 32 & 25 & 20 & 32 & 30 & 5 & 413 \\
\hline VN-16 & 50 & 50 & 75 & 50 & 24 & 50 & 8 & 25 & 25 & 32 & 18 & 5 & 412 \\
\hline BT-124 & 40 & 50 & 75 & 50 & 40 & 20 & 40 & 25 & 20 & 16 & 30 & 5 & 411 \\
\hline ML-44 & 50 & 50 & 75 & 40 & 24 & 40 & 32 & 25 & 20 & 32 & 18 & 5 & 411 \\
\hline ML-64 & 50 & 50 & 75 & 40 & 24 & 40 & 32 & 25 & 20 & 32 & 18 & 5 & 411 \\
\hline VN-17 & 50 & 50 & 75 & 40 & 24 & 20 & 40 & 25 & 20 & 32 & 30 & 5 & 411 \\
\hline VN-50 & 50 & 50 & 75 & 40 & 24 & 40 & 32 & 25 & 20 & 32 & 18 & 5 & 411 \\
\hline $\mathrm{BN}-12$ & 40 & 50 & 75 & 50 & 24 & 40 & 32 & 25 & 20 & 32 & 18 & 5 & 411 \\
\hline HK-51 & 40 & 50 & 75 & 50 & 24 & 50 & 32 & 10 & 20 & 32 & 18 & 5 & 406 \\
\hline $\mathrm{BN}-25$ & 40 & 50 & 75 & 50 & 24 & 50 & 32 & 20 & 10 & 32 & 18 & 5 & 406 \\
\hline BT-5 & 40 & 50 & 75 & 40 & 24 & 40 & 40 & 20 & 20 & 32 & 18 & 5 & 404 \\
\hline ML-71 & 40 & 50 & 75 & 50 & 24 & 20 & 32 & 25 & 20 & 32 & 30 & 5 & 403 \\
\hline MŞ-24 & 40 & 50 & 75 & 40 & 24 & 20 & 40 & 25 & 20 & 32 & 30 & 5 & 401 \\
\hline ML-50 & 40 & 50 & 75 & 40 & 24 & 40 & 32 & 25 & 20 & 32 & 18 & 5 & 401 \\
\hline \multicolumn{14}{|c|}{ Bodur taze fasulye } \\
\hline ML-20 & 40 & 50 & 75 & 50 & 24 & 40 & 40 & 20 & 20 & 32 & 30 & 25 & 446 \\
\hline HK-8 & 20 & 50 & 75 & 50 & 24 & 50 & 40 & 10 & 20 & 40 & 30 & 25 & 434 \\
\hline Yalova-17 & 50 & 50 & 75 & 40 & 40 & 50 & 8 & 25 & 20 & 32 & 18 & 25 & 433 \\
\hline ML-30 & 40 & 50 & 75 & 20 & 24 & 50 & 32 & 20 & 20 & 32 & 30 & 25 & 418 \\
\hline BT-68 & 40 & 50 & 75 & 50 & 24 & 40 & 8 & 20 & 20 & 32 & 30 & 25 & 414 \\
\hline ML-25 & 20 & 50 & 75 & 40 & 8 & 50 & 40 & 20 & 20 & 32 & 30 & 25 & 410 \\
\hline Yalova-5 & 40 & 50 & 75 & 40 & 24 & 40 & 8 & 25 & 20 & 32 & 30 & 25 & 409 \\
\hline HK-18 & 10 & 50 & 75 & 40 & 24 & 50 & 32 & 20 & 20 & 32 & 30 & 25 & 408 \\
\hline ML-60 & 20 & 50 & 75 & 50 & 24 & 40 & 32 & 20 & 20 & 32 & 18 & 25 & 406 \\
\hline HK-33 & 20 & 50 & 75 & 40 & 8 & 50 & 32 & 20 & 20 & 32 & 30 & 25 & 402 \\
\hline
\end{tabular}

BȘ: Bakla Sekli, BG: Baklada Gevreklik, BK: Baklada Kılçıklııı, BR: Bakla Rengi, BKıv: Baklada Kıvrılma, SBS: Salkımda Bakla Sayısı, BBS: Bitkide Bakla Sayısı, ÇD: Çiçeklenme Durumu, E: Erkencilik, BTB: Bakla Tohumunun Belirginliği, BP: Baklada Pürüzlülük, BG: Bitki Görünümü 


\section{Sonuç ve Öneriler}

Ülkemizde geniş bir alanda yetiştiriciliği yapılan fasulyenin anavatanı Orta Amerika'dır (Balkaya ve Gülümser, 1999). Doğu Anadolu Bölgesi'nin güneyinde yetiştiriciliği yapılan fasulye popülasyonu, 1slah çalışmaları için önemli bir kaynak sağlamaktadır. Çalışmada kullanılan genotipler üzerinde yürütülen fenolojik gözlemler sonucunda, taze fasulye gen kaynakları tespit edilmiş ve teksel seleksiyon metoduyla belirlenen ümitvar hatlar saptanmıştır.

Doğu Anadolu Bölgesi'nin güneyinde 8 ilden 378 fasulye genotipi toplanmıştır. Bölgede karışık tohum kullanıldığından dolayı üreticiden alınan bilgiler doğrultusunda tohumların şekline ve renklerine bakılarak materyaller çalışmada kullanılmıştır. Çalışmada kullanılan genotiplere ait bilgiler kayıt altına alınmış ve bu hatlar Menemen Tarımsal Araştırma Enstitüsü'ndeki Gen Bankası'na gönderilmiştir.

Araştırmada, 2010 yılında tarla denemesine alınan 378 hat içerisinden tartılı derecelendirme metoduyla ilk yıl, 62 taze sırık ve 26 taze bodur hat; ikinci yıl, 88 hat içerisinden 30 taze sırık ve 8 taze bodur hat ümitvar olarak tespit edilmiştir. Çalışma neticesinde elde edilen sırık ve bodur hatlar ile birlikte tartılı derecelendirmede 400 puanı alamayan diğer 340 genotip, fenolojik özelikler bakımından değerlendirilmiştir. Elde edilen ve değerlendirilmeye tabi tutulan hatlar, bundan sonra yapılması planlanmakta olan melezleme ve kombinasyon 1slahı çalışmaları ile çeşit geliştirmede çok önemli kaynak olacaktır. Seçilen 38 genotipte akrabalı derecelerini belirlemeye yönelik çalışmalar da ileride yapilacaktır. Deneme sonucunda elde edilen 30 sırık ve 8 bodur fasulye genotipinde çeşit geliştirme çalışmalarının devam etmesi öngörülmektedir. Bu çalışmanın neticesinde elde edilen hatlarla Doğu Anadolu'da ve diğer tüm bölgelerimizde taze tüketime uygun yeni çeşitler geliştirilebileceği kanısındayız.

\section{Teşekkür}

Bu çalışmada, maddi katkılarından dolayı Türkiye Bilimsel ve Teknolojik Araştırma Kurumu (TÜBİTAK) Başkanlığı'na teşekkür ederiz.

\section{Kaynaklar}

Adams, M.W., Coyne, D.P., Davis, J.H.C., Graham, P.H., Francis, C.A., 1985. Common bean (Phaseolus vulgaris L.). In: R.J. Summerfield and E.H. Roberts (Eds.), Grain Legume Crops, Collins Professional and Technical Books, London, GB.1985, p. 433476.
Anonim, 2011. Meteoroloji Bölge Müdürlüğü kayıtları, Van.

Anonymous, 1982. Descriptors for Phaseolus vulgaris. International Plant Genetic Resources Institute (IPGR), Rome, Italy.

Anonymous, 2009. Protocol for Distinctness, Uniformity and Stability Tests, Phaseolus vulgaris L. Community Plant Variety Office (CPVO), UPOV Code: PHASE_VUL.

Balkaya, A., 1999. Karadeniz Bölgesi'ndeki taze fasulye (Phaseolus vulgaris L.) gen kaynaklarının toplanmas1, fenolojik ve morfolojik özelliklerinin belirlenmesi ve taze tüketime uygun tiplerin teksel seleksiyon yöntemi ile seçimi üzerinde araştırmalar. Doktora tezi, Ondokuz Mayis Üniversitesi Fen Bilimleri Enstitüsü, Bahçe Bitkileri Ana Bilim Dal, Samsun.

Balkaya, A., Gülümser, A., 1999. Karadeniz Bölgesi'nde taze fasulye üretim durumu. Karadeniz Bölgesi Tarım Sempozyumu, Bildiriler Kitabı, Cilt-2, 4-5 Ocak, Samsun, s. 557-568.

Benchimol, L.L., De Campos, T., Carbonell, S.A.M., Colombo, C.A., Chioratto, A.F., Formighieri, E.F., Gouvêa, L.R.L., De Souza, A.P., 2007. Structure of genetic diversity among common bean (Phaseolus vulgaris L.) varieties of Mesoamerican and Andean origins using new developed microsatellite markers. Genetic Resources and Crop Evolution, 54(8): 1747 1762.

Chacon, S.M.I., Pickersgill, B., Debouck, D.G., 2005. Domestication patterns in common bean (Phaseolus vulgaris $\mathrm{L}$.) and the origin of the Mesoamerican and Andean cultivated races. Theoretical and Applied Genetics, 110(3): 432-444.

Chiorato, A.F.., Carbonell, S.A.M., Benchimol, L.L., Chiavegato, M.B., Dias, L.A.S., Colombo, C.A., 2007. Genetic diversity in common bean accessions evaluated by means of morpho-agromonical and RAPD data. Scientia Agricola, 64(3): 256-262.

Duke, J.A., 1983. Phaseolus vulgaris L. In: Handbook of Energy Crops (unpublished). Purdue University, Center for New Crops \& Plants Products, West Lafayette, Indiana.

Kwak, M., Gepts, P., 2009. Structure of genetic diversity in the two major gene pools of common bean (Phaseolus vulgaris L., Fabaceae). Theoretical and Applied Genetics, 118(5): 979-992.

Marotti, I., Bonetti, A., Minelli, M., Catizone, P., Dinelli, G., 2007. Characterization of some Italian common bean (Phaseolus vulgaris L.) landraces by RAPD, semi- random and ISSR molecular markers. Genetic Resources and Crop Evolution, 54(1): 175188.

Singh, S.P., 2001. Broadening the genetic base of common bean cultivars. Crop Science, 41(6): 16591675.

Woolley, J., Ildefonso, R.L., Castro, T.A.P., Voss, J., 1991. Bean cropping systems in the tropics and subtropics and their determinants. Field Crops Abstract, 11: 8227. 